The Relationship between the Use of Social Media and Social Relations among University Students

Samar. S. Omar, (Ph.D.)

Anwaar. R. M. Elsayed, (Ph.D.)

Department of Social Work Fields

Faculty of Social Work- Helwan University, Cairo, Egypt 


\section{The Relationship Between The Use of Social Media And Social Relations Among University Students}

Samar. S. Omar, (Ph.D.)

Anwaar. R. M. Elsayed, (Ph.D.)

Department of Social Work Fields

Faculty of Social Work- Helwan University, Cairo, Egypt

\section{Abstract:}

This study aimed to determine the relationship between social media and social relations among university students, users and nonusers of social media. It also aimed to Identify indicators for social workers to enable them to work with to support the social relationships for university students, users of social media, from social and natural science disciplines. The study population comprised the whole student body of Helwan University with all its faculties. The total sample of the research was 210 students, where 95 students were from social science disciplines (specifically Faculty of Social Work and Faculty of Arts), and 115 students were from natural science disciplines (specifically Faculty of Pharmacy and Faculty of Sciences).

The study concluded that there are differences between the social media user and non-user students from social science disciplines, and no differences between user and non-user students from natural science disciplines on the social relations scale. However, there are differences between the mean scores of social media non-user students from social science disciplines and those from natural science disciplines on the social relations scale

\section{Keywords:}

Social media, social relationships, university youth, users and non-users of social media.

\section{Introduction:}

Youth is the time of life when a person is young, especially the time before a child becomes an adult (Deuter Margaret and others, 2015, p.1816)

Youth is considered the heart and pulse of any state. The strength of a state is determined by the strength of its youth, because it is through youth that a state progresses and achieves its objectives. Hence, communities give attention to youth, providing them with comprehensive services through several institutions to meet their 
needs and address their problems. This age bracket needs special treatment, from a community development perspective, to ensure its social and economic progress (Abu Al-Maati, 2008, p. 259).

University youth is one of the social groups that the state is concerned with because it affects its safety and security. It is an age bracket interspersed with some characteristics of other age brackets. It is defined as the stage where an individual is freed of childhood experiences, and learns the new roles that s/he will lead as an adult. In this stage, experiences towards the future and the surrounding environment are still undefined (Al-Wageez, 1997, p. 333)

Social media is the latest development on the Internet, and is accompanied by the emergence of many web technologies. Numerous internet specialists indicate that social media is a great leap forward for greater interaction in communication than before, when communication was limited and little information was shared. Social media has provided many opportunities such as sharing information among all network subscribers, with the possibilities of direct and free interaction on social media sites. Such sites are considered internet based tools, used to improve and share content, to communicate with others, and affect and be affected by others. In other words, they are tools for knowledge, information, and cultural exchanged between members of a community and between one community and another. They also facilitate exchange of experiences and skills, and the acquisition of different cultures and social habits among the society elements at a lower cost, faster speed, and using modern methods. The internet has given way to the emergence of several social networking sites such as Facebook and Twitter, and other sites designed for that purpose (Abdul Jawad, 2017, pp. 70-71)

Some of the most prominent and popular means of social communication on the internet are Facebook, Twitter, Instagram, and Google. Technology currently dominates the cultures of peoples. Today, social media represents the most prominent influence in our society as it attracts large segments of people, especially youth, which is considered the most influential segment in society in terms of energy, capacities, and ability to change and develop. Thus, social media affects the social values of youth, as confirmed by Khaled's study (Saleh Khaled, 2012). 
Technology has become influential on the social relations of young people, positively and negatively, such as the infrequency of visiting and substituting visits with short messages via Facebook. This was confirmed by Shashou' in her study, which indicated that female students became able to express their opinions and thoughts where they could not otherwise, and to communicate with their relatives (Hanan Shashou', 2012). Negative effects include the lack of interaction with their families, as well as other negative effects on the psychological, physical, educational, and social aspects, as confirmed by Zaghloul's study (Abbas Zaghloul, 2006).

In addition, a study by Wafaa Abdul Salam (2012) indicated that online communication leads to the expansion of the individual's social relationships with others on the local, regional and international level, regardless of his/her nationality, social, and political background. It provides individuals with an opportunity to present themselves to others great freely. Their usage of this type of communication could turn into an addiction, which affects their behavior and their social relationships with others. Excessive use of internet and social media might also result in weak interaction, participation and social isolation of young people from surrounding people like family, relatives, friends, and neighbors, as was confirmed in Khateiry's and El Tayar's studies (Merval Khtateiry, 2014, and Fahd El Tayar, 2014). El Tayar's study found that social media have negative impact on changing social values among university students.

In his study, Yang affirmed that "social media users' online activities in terms of information broadcasting, information seeking and relational maintenance, aimed at investigating how college students' SNS usage patterns may affect their online social network sizes. Statistics in this chapter suggested that more information seeking leads to more Twitter followings while more information broadcasting results in a larger size of Twitter followers. The frequency of relationship management, however, did not predict students' social network size on either Twitter or Facebook. Implications of the study were discussed" (Yang, Chen and others, 2015).

Weiss D (2014) revealed in her study the effect of using social media on oneself. "The use of the internet as a social medium has been demonstrated to have both positive and negative consequences 
and the question of who uses these Social Media Sites (SNSs), and why, is one of interest and concern. Better understanding of who uses SNSs and why they choose to, can help target interventions toward those for whom SNS use may lead to problematic outcomes and encourage the use of those for whom SNSs are beneficial. Many researchers, following the indications of social network theory, looked to personality traits and features in order to explain SNS activity, and found significant support for this "rich get richer" theory" Weiss, Diana E. (2014).

As a profession, social work pays much attention to human development, focusing on effecting necessary social changes in individuals, groups, and communities, in order to improve their relationships with others. In addition, youth care is considered one of the fields where social work plays an important role. Through practice in the field of youth care, social work seeks to support the university system. Social workers, being part of the education system, and possessing information and skills, seek to achieve several objectives, including promoting the sense of belonging among university youth and protecting them against intellectual polarization (Abu El Maaty Maher, 1999, p.32).

\section{Study Goals:}

1) Determine the relationship between the use of social media and social relations of university youth with the structures of family, friends, faculty members, and university.

2) Identify indicators for social workers to enable them to work with to support the social relationships for university students, users of social media, from social and natural science disciplines.

\section{Study Hypotheses:}

1. First Hypothesis: There are statistically significant differences between the mean scores of social media users from social sciences disciplines and the mean scores of non-users on the social relations scale.

2. Second Hypothesis: There are statistically significant differences between the mean scores of social media users from natural sciences disciplines and the mean scores of nonusers on the social relations scale. 
3. Third Hypothesis: There are statistically significant differences between the mean scores of social media users from social sciences disciplines and the mean scores of social media users from natural sciences disciplines on the social relations scale.

4. Fourth Hypothesis: There are statistically significant differences between the mean scores of the non-users of social media from social sciences disciplines and the mean scores of the non-users of social media from natural sciences disciplines on the social relations scale.

\section{Study Concepts:}

\section{Social Relations:}

They are the relations that occur between an individual and another, where interactions and response exist between them. Relations represent the main basis of all social processes (Badawy, 1993, p. 394).

It is an example of social interaction between two or more persons that involves meaningful communication and knowledge of the other person's behavior. The length of a social relationship varies (Gheith, p. 437).

The way in which two people groups or countries behave towards each other or deal with each other (Deuter, Margaret and others, 2015 p.1301).

It is also defined as the mutual bonds between individuals and the society, arising from their interactions and exchange of feelings. Social relations that arise between individuals are among the most important necessities of life. They could be temporary, long term, or limited (Husseing Ghani Nasser, 2012, p. 125).

The procedural definition of social relations in this study is:

The social interactions that take place between the university youth and the surrounding systems such as colleagues, family, faculty members, and the university.

\section{Theories guiding the study:}

The scientific theories on which social work is based are characterized by several characteristics including:

- Theories are derived from other sciences. This rule is not based on any particular science.

- The general practice in social work is based on the theory of systems and the communication theory. This framework provides a 
deeper and more comprehensive view of how different systems interact.

- The selection of scientific theories takes place in the light of the requirements of field practice and the objectives pursued by the profession (Abdullatif and Dandrawy, 2001, p. 60).

The following is a presentation of these theories:

\section{General systems theory:}

The general systems theory is one of the basic tributaries of general practice in social work and a general framework or collection of all theories, a broad method of thinking and understanding, and a broad reference method for information analysis.

1- The open system is a system that receives outside inputs according to its needs and limits in this regard. It is supported by the external environment and characterized by a feedback process that ensures its balance and its internal and external adaptation.

The institution is an open social system where interaction, dependence and exchange with the surrounding society exist (Abdullatif, 1999, p. 164).

Thus, university is considered an open social system where interaction and interdependence with outside society exist.

2- Role: The systems theory refers to the concept of role and its importance in the framework of the system. The role refers to the system of behaviors of the person holding a position or a specific function in the institution. This moral system consists of behaviors, human relationships, and professional relationships related to the activities and responsibilities of the role and its performance.

Therefore, each system has a role to play (Suleiman Hussein et al., 2005, p. 292).

\section{Communication Theory:}

Communication is the process through which knowledge is transferred from one person to another, until it becomes mutual. Means of Communication:

Direct means such as personal meetings, field visits, and participations in public events.

Indirect means such as newspapers, radio, pictures, and computers (Abdel Fattah Mohammed, 2011, p. 168).

Elements of Communication: 
Message: It is the content to be transmitted from the sender to the receiver, which could be information or ideas.

Sender: The entity through which the message that the owner wants to deliver to the receiver is issued.

Receiver: The person that the sender targets by the message with the purpose of sharing information. Youth could be senders or receivers.

Method: The method through which the content is transferred. This includes social media such as Facebook, Twitter, and WhatsApp (Kamal Ahmed, p. 67).

\section{Research Limits:}

Subject Limit: The relationship between using social media and social relations among university youth.

Human Limit: The study was applied to 210 male and female students at Helwan University, of which 95 students were from social science disciplines, and 115 were from natural science disciplines. Students selected were at least 19 years old and non-addicted to social media, i.e. not spending a large amount of time using social media on a daily basis.

Place Limit: The study was implemented in social science faculties (such as the Faculty of Social Work and the Faculty of Arts) and natural science faculties (such as the Faculty of Pharmacy and the Faculty of Sciences) at Helwan University in Cairo, Egypt.

Time Limit: The study was implemented during the period from 14/04/2016 to $24 / 05 / 2016$.

\section{Methodology:}

The study is of the descriptive type, based on the social survey method, applied on a sample of Helwan University students from theoretical and practical faculties. The study used a social relationship scale designed by the researchers.

\section{Validity and Reliability of the Study Tool:}

Table (1) - Results of the Reliability of the Social Relations Scale Using the Alpha Cronbach Coefficient

\begin{tabular}{|c||c|c||}
\hline \hline Srl. & Dimensions & $\begin{array}{c}\text { Alpha } \\
\text { Cronbach } \\
\text { Coefficient }\end{array}$ \\
\hline \hline 1 & Social relations dimension regarding the friends system & 0.83 \\
\hline
\end{tabular}




\begin{tabular}{||c||l||c||}
\hline Srl. & \multicolumn{1}{|c||}{ Dimensions } & $\begin{array}{c}\text { Alpha } \\
\text { Cronbach } \\
\text { Coefficient }\end{array}$ \\
\hline \hline 2 & Social relations dimension regarding the family system & 0.80 \\
\hline \hline 3 & $\begin{array}{l}\text { Social relations dimension regarding the faculty } \\
\text { members system }\end{array}$ & 0.86 \\
\hline \hline 4 & $\begin{array}{l}\text { Social relations dimension regarding the university } \\
\text { system }\end{array}$ & 0.84 \\
\hline \hline & Total Dimensions & $\mathbf{0 . 8 7}$ \\
\hline
\end{tabular}

The table above shows that most of the coefficients of the variables have a high degree of reliability, thus their results are reliable, and the tool is finalized.

Description of the Study Community:

Table (2) - Distribution of University Youth by Gender $\quad(\mathrm{N}=210)$

\begin{tabular}{|c|c|c|c|c|c|c|c|}
\hline \multirow{2}{*}{ Serial } & \multirow{2}{*}{$\begin{array}{l}\text { Specialization } \\
\text { Gender }\end{array}$} & \multicolumn{2}{|c|}{$\begin{array}{c}\text { Social Sciences } \\
\mathrm{N}=(95)\end{array}$} & \multicolumn{2}{|c|}{$\begin{array}{c}\text { Natural Sciences } \\
\mathrm{N}=(\mathbf{1 1 5}) \\
\end{array}$} & \multicolumn{2}{|c|}{$\begin{array}{c}\text { Total } \\
\mathrm{N}=(210)\end{array}$} \\
\hline & & $\mathbf{N}$ & $\%$ & $\mathbf{N}$ & $\%$ & $\mathbf{N}$ & $\%$ \\
\hline 1 & Male & 70 & 73.7 & 85 & 73.9 & 155 & 73.8 \\
\hline 2 & Female & 25 & 26.3 & 30 & 26.1 & 55 & 26.2 \\
\hline & Total & 95 & $\bar{~} 100.0$ & 115 & $\overline{c 100.0}$ & 210 & $\overline{100.0}$ \\
\hline
\end{tabular}

The table above shows that:

- The highest percentage of university students from social science disciplines were male (73.7\%), while females were $(26.3 \%)$.

- The highest percentage of university students from natural science disciplines were male (73.9\%), while females were $(26.1 \%)$.

Table (3) - Distribution of University Youth by Age $\quad(\mathrm{N}=210)$

\begin{tabular}{|c|c|c|c|c|c|c|c|}
\hline \multirow{2}{*}{ Serial } & \multirow[t]{2}{*}{ Specialization } & \multicolumn{2}{|c|}{$\begin{array}{c}\text { Social Sciences } \\
\mathrm{N}=(\mathbf{9 5})\end{array}$} & \multicolumn{2}{|c|}{$\begin{array}{c}\text { Natural Sciences } \\
\quad N=(\mathbf{1 1 5})\end{array}$} & \multicolumn{2}{|c|}{$\begin{array}{c}\text { Total } \\
\mathrm{N}=(\mathbf{2 1 0})\end{array}$} \\
\hline & & $\mathbf{N}$ & $\%$ & $\mathbf{N}$ & $\%$ & $\mathbf{N}$ & $\%$ \\
\hline 1 & $19+$ & 33 & 34.7 & $\overline{51}$ & 44.3 & 84 & 40 \\
\hline 2 & $21+$ & 51 & 53.7 & 45 & 39.1 & 96 & 45.7 \\
\hline 3 & $23+$ & 11 & 11.6 & 19 & 16.5 & 30 & 14.3 \\
\hline & Total & 95 & 100.0 & 115 & 100.0 & 210 & 100.0 \\
\hline \multicolumn{2}{|c|}{ Arithmetic Mean } & \multicolumn{2}{|c|}{22} & \multicolumn{2}{|c|}{21} & \multicolumn{2}{|c|}{21} \\
\hline \multicolumn{2}{|c|}{ Standard Deviations } & \multicolumn{2}{|c|}{1} & \multicolumn{2}{|c|}{$\overline{11}$} & \multicolumn{2}{|c|}{1} \\
\hline
\end{tabular}

The table above shows that: 
- The highest percentage of university students from social science disciplines were from the age bracket (21-23 years) with a percentage of $(53.7 \%)$, followed by the age bracket (19-21 years) with a percentage of $34.7 \%$ ), and finally the age bracket (23-25 years) with a percentage of $(11.6 \%)$. The mean age of university youth from social science disciplines is 22 years, with a standard deviation of 1 year.

- The highest percentage of university students from natural science disciplines were from the age bracket (19-21 years) with a percentage of (44.3\%), followed by the age bracket (21-23 years) with a percentage of $39.1 \%$ ), and finally the age bracket (23-25 years) with a percentage of $(16.5 \%)$. The mean age of university youth from social science disciplines is 21 years, with a standard deviation of 1 year.

Table (4) - Distribution of University Youth by Use of Social Media $\quad(\mathrm{N}=210)$

\begin{tabular}{|c|c|c|c|c|c|c|c|}
\hline \multirow{2}{*}{ Serial } & \multirow{2}{*}{$\begin{array}{l}\text { Specialization } \\
\text { Social } \\
\text { Media Use }\end{array}$} & \multicolumn{2}{|c|}{$\begin{array}{c}\text { Social Sciences } \\
\mathrm{N}=(\mathbf{9 5})\end{array}$} & \multicolumn{2}{|c|}{$\begin{array}{c}\text { Natural Sciences } \\
\quad \mathrm{N}=(\mathbf{1 1 5}) \\
\end{array}$} & \multicolumn{2}{|c|}{$\begin{array}{c}\text { Total } \\
\mathrm{N}=(\mathbf{2 1 0}) \\
\end{array}$} \\
\hline & & $\mathbf{N}$ & $\%$ & $\mathbf{N}$ & $\%$ & $\mathbf{N}$ & $\%$ \\
\hline 1 & Users & 52 & 45.7 & 60 & 52.2 & 112 & 53.3 \\
\hline 2 & Non-Users & 43 & 45.3 & 55 & 47.8 & 98 & 46.7 \\
\hline & Total & 95 & 100.0 & 115 & 100.0 & 210 & 100.0 \\
\hline
\end{tabular}

\section{The table above shows that:}

- The highest percentage of university students from social science disciplines were social media users with a percentage of $(54.7 \%)$, while non-users were $(45.3 \%)$.

The highest percentage of university students from natural science disciplines were social media users with a percentage of $(52.2 \%)$, while non-users were $(47.8 \%)$. This may be due to the nature of practical disciplines that requires higher use of social media than theoretical faculties.

(1-1) Testing the first hypothesis: There are statistically significant differences between the mean scores of social media users from social sciences disciplines and the mean scores of non-users on the social relations scale. 
Table (5) - Significant Differences between the Mean Scores of Users of Social Media from Social Science Disciplines and the Mean Scores of Non-Users on the Social Relationships Scale Using T-Test (N=95)

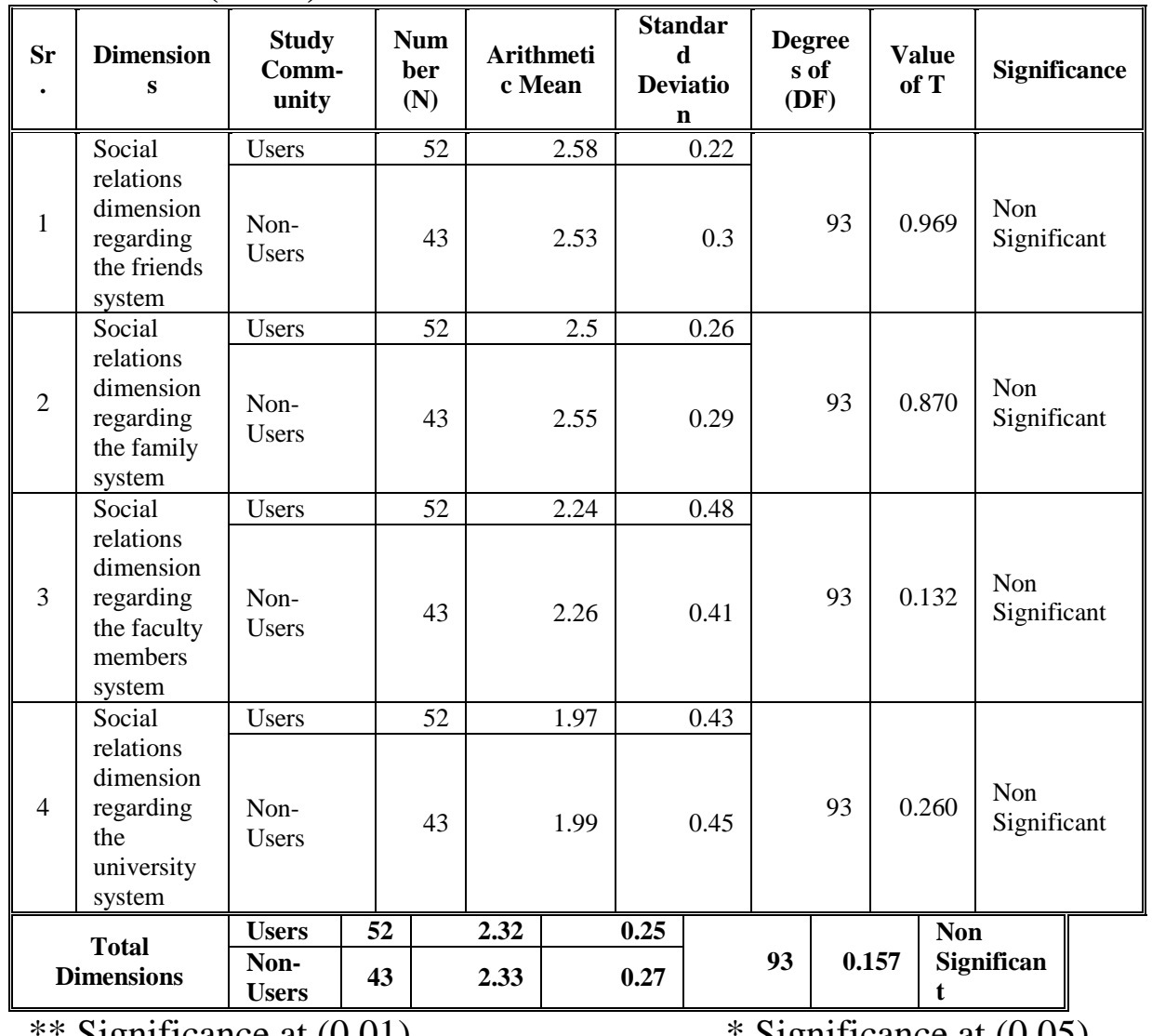

** Significance at (0.01)

* Significance at $(0.05)$

The table above shows that there are no statistically significant differences between the mean scores of social media users from social science disciplines and the mean scores of non-users of social media on the social relationships scale. This result disagrees with the study of Hanan Shashou' (2012) who asserted the presence of negative effects of social media on the social relationships of university youth. This may be due to the difference in the study community and the period of implementation of the study, as well as the duration of social media usage among university youth. 
Thus, we reject the first study hypothesis: There are statistically significant differences between the mean scores of social media users from social sciences disciplines and the mean scores of non-users on the social relations scale.

(1-2) Testing the second hypothesis: There are statistically significant differences between the mean scores of social media users from natural sciences disciplines and the mean scores of non-users on the social relations scale.

\section{Table (6) - Significant Differences between the Mean Scores of} Users of Social Media from Natural Science Disciplines and the Mean Scores of Non-Users on the Social Relationships Scale Using

\section{T-Test}

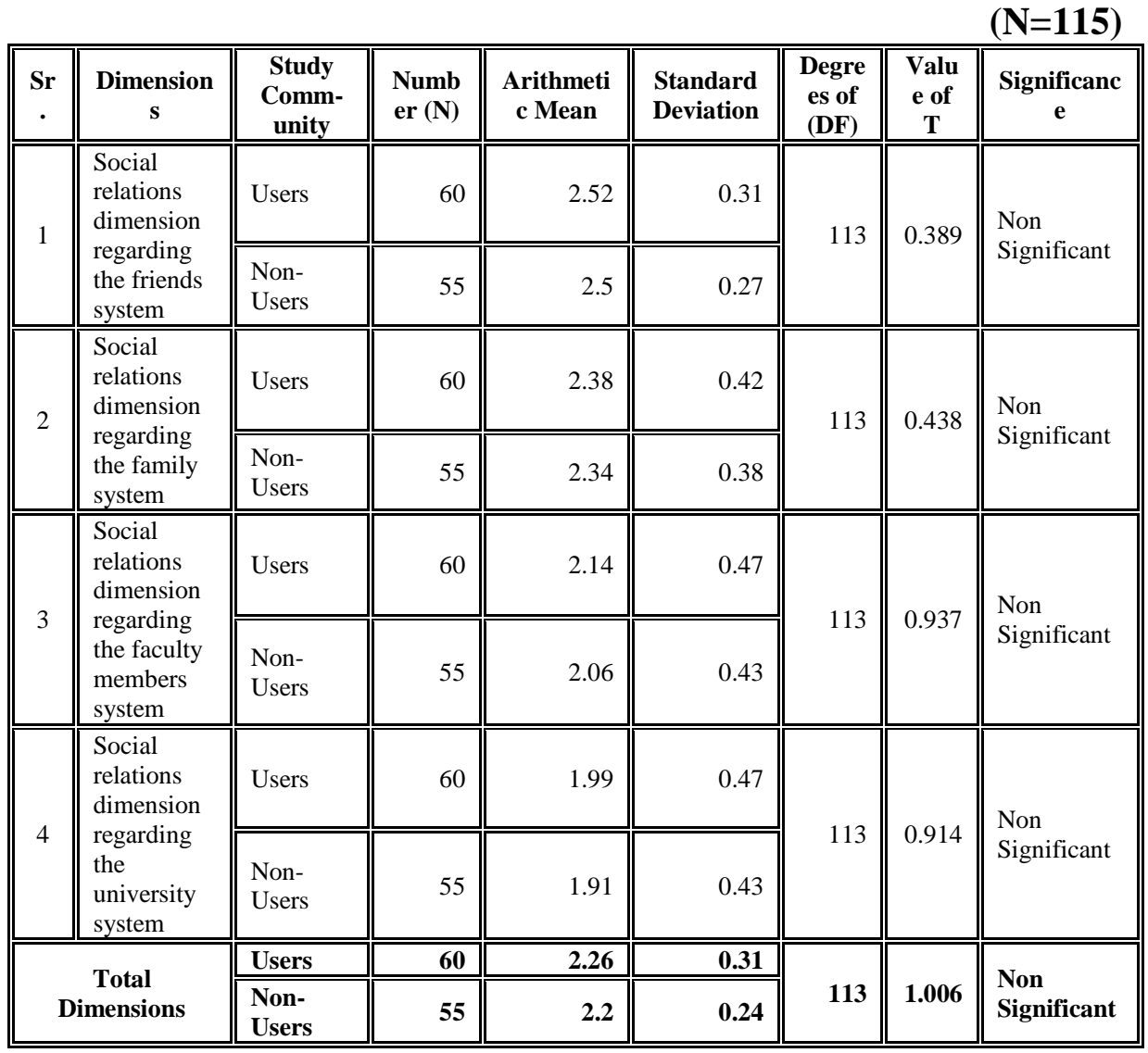

** Significance at $(0.01)$

* Significance at $(0.05)$ 
The table above shows that there are no statistically significant differences between the mean scores of social media users from natural science disciplines and the mean scores of non-users of social media on the social relationships scale.

Thus, we reject the second study hypothesis: There are statistically significant differences between the mean scores of social media users from natural sciences disciplines and the mean scores of non-users on the social relations scale.

(1-3) Testing the third hypothesis: There are statistically significant differences between the mean scores of social media users from social sciences disciplines and the mean scores of social media users from natural sciences disciplines on the social relations scale.

Table (7) - Significant Differences between the Mean Scores of Users of Social Media from Social Science Disciplines and the Mean Scores of Users of Social Media from Natural Science Disciplines on the Social Relationships Scale Using T-Test $(\mathbf{N}=112)$

\begin{tabular}{|c|c|c|c|c|c|c|c|c|}
\hline $\begin{array}{c}\mathrm{Sr} \\
.\end{array}$ & $\begin{array}{c}\text { Dimension } \\
\mathbf{s}\end{array}$ & $\begin{array}{c}\text { Study } \\
\text { Comm- } \\
\text { unity }\end{array}$ & $\begin{array}{l}\text { Numbe } \\
\mathbf{r}(\mathbf{N})\end{array}$ & $\begin{array}{l}\text { Arithmeti } \\
\text { c Mean }\end{array}$ & $\begin{array}{c}\text { Standar } \\
\text { d } \\
\text { Deviatio } \\
\text { n }\end{array}$ & $\begin{array}{c}\text { Degree } \\
\text { s of } \\
\text { (DF) }\end{array}$ & $\begin{array}{c}\text { Valu } \\
\text { e of } \\
T\end{array}$ & $\begin{array}{c}\text { Significanc } \\
\text { e }\end{array}$ \\
\hline \multirow{2}{*}{1} & \multirow{2}{*}{$\begin{array}{l}\text { Social } \\
\text { relations } \\
\text { dimension } \\
\text { regarding } \\
\text { the friends } \\
\text { system } \\
\end{array}$} & $\begin{array}{l}\text { Social } \\
\text { Science } \\
\mathrm{s}\end{array}$ & 52 & 2.58 & 0.22 & \multirow{2}{*}{110} & \multirow{2}{*}{1.194} & \multirow{2}{*}{$\begin{array}{l}\text { Non } \\
\text { Significant }\end{array}$} \\
\hline & & $\begin{array}{l}\text { Natural } \\
\text { Science } \\
\mathrm{s}\end{array}$ & 60 & 2.52 & 0.31 & & & \\
\hline \multirow{2}{*}{2} & \multirow{2}{*}{$\begin{array}{l}\text { Social } \\
\text { relations } \\
\text { dimension } \\
\text { regarding } \\
\text { the family } \\
\text { system }\end{array}$} & $\begin{array}{l}\text { Social } \\
\text { Science } \\
\mathrm{s}\end{array}$ & 52 & 2.5 & 0.26 & \multirow{2}{*}{110} & \multirow{2}{*}{1.839} & \multirow{2}{*}{$\begin{array}{l}\text { Non } \\
\text { Significant }\end{array}$} \\
\hline & & $\begin{array}{l}\text { Natural } \\
\text { Science } \\
\text { s }\end{array}$ & 60 & 2.38 & 0.42 & & & \\
\hline \multirow{2}{*}{3} & \multirow{2}{*}{$\begin{array}{l}\text { Social } \\
\text { relations } \\
\text { dimension } \\
\text { regarding } \\
\text { the faculty } \\
\text { members } \\
\text { system } \\
\end{array}$} & $\begin{array}{l}\text { Social } \\
\text { Science } \\
\text { s }\end{array}$ & 52 & 2.24 & 0.48 & \multirow{2}{*}{110} & \multirow{2}{*}{1.174} & \multirow{2}{*}{$\begin{array}{l}\text { Non } \\
\text { Significant }\end{array}$} \\
\hline & & $\begin{array}{l}\text { Natural } \\
\text { Science } \\
\mathrm{s}\end{array}$ & 60 & 2.14 & 0.47 & & & \\
\hline \multirow{2}{*}{4} & \multirow{2}{*}{$\begin{array}{l}\text { Social } \\
\text { relations } \\
\text { dimension } \\
\text { regarding } \\
\text { the } \\
\text { university } \\
\text { system }\end{array}$} & $\begin{array}{l}\text { Social } \\
\text { Science } \\
\text { s }\end{array}$ & 52 & 1.97 & 0.43 & \multirow{2}{*}{110} & \multirow{2}{*}{0.205} & \multirow{2}{*}{$\begin{array}{l}\text { Non } \\
\text { Significant }\end{array}$} \\
\hline & & $\begin{array}{l}\text { Natural } \\
\text { Science } \\
\mathrm{s}\end{array}$ & 60 & 1.99 & 0.47 & & & \\
\hline & Total & Social & 52 & 2.32 & 0.25 & 110 & 1.264 & Non \\
\hline
\end{tabular}




\begin{tabular}{|c|c|c|c|c|c|c|c|c|}
\hline $\begin{array}{c}\mathrm{Sr} \\
\cdot\end{array}$ & $\begin{array}{c}\text { Dimension } \\
\mathbf{S}\end{array}$ & $\begin{array}{c}\text { Study } \\
\text { Comm- } \\
\text { unity }\end{array}$ & $\begin{array}{l}\text { Numbe } \\
\mathbf{r}(\mathbf{N})\end{array}$ & $\begin{array}{l}\text { Arithmeti } \\
\text { c Mean }\end{array}$ & $\begin{array}{c}\text { Standar } \\
\text { d } \\
\text { Deviatio } \\
\text { n } \\
\end{array}$ & $\begin{array}{c}\text { Degree } \\
\text { s of } \\
\text { (DF) }\end{array}$ & $\begin{array}{c}\text { Valu } \\
\text { e of } \\
\mathbf{T}\end{array}$ & $\begin{array}{c}\text { Significanc } \\
\mathrm{e}\end{array}$ \\
\hline \multirow{2}{*}{\multicolumn{2}{|c|}{ Dimensions }} & $\begin{array}{l}\text { Science } \\
\text { S }\end{array}$ & & & & & & \multirow[t]{2}{*}{ Significant } \\
\hline & & $\begin{array}{l}\text { Natural } \\
\text { Science } \\
\text { s }\end{array}$ & 60 & 2.26 & 0.31 & & & \\
\hline
\end{tabular}

** Significance at $(0.01)$

* Significance at $(0.05)$

The table above shows that there are no statistically significant differences between the mean scores of users of social media from social science disciplines and the mean scores of users of social media from natural science disciplines on the social relations scale.

Thus, we reject the third study hypothesis: There are statistically significant differences between the mean scores of social media users from social sciences disciplines and the mean scores of social media users from natural sciences disciplines on the social relations scale.

(1-4) Testing the fourth hypothesis: There are statistically significant differences between the mean scores of the non-users of social media from social sciences disciplines and the mean scores of the non-users of social media from natural sciences disciplines on the social relations scale.

Table (8) - Significant Differences between the Mean Scores of Non-Users of Social Media from Social Science Disciplines and the Mean Scores of Non-Users of Social Media from Natural Science Disciplines on the Social Relationships Scale Using T-Test

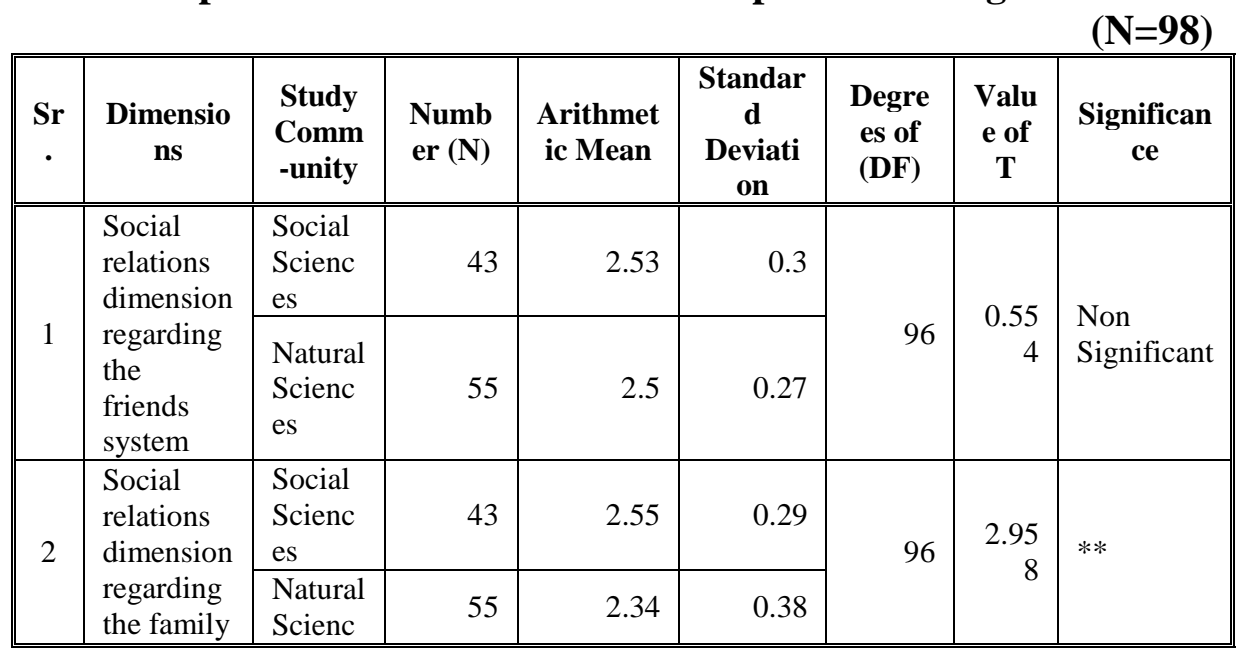




\begin{tabular}{|c|c|c|c|c|c|c|c|c|}
\hline $\begin{array}{c}\mathrm{Sr} \\
.\end{array}$ & $\underset{n s}{\text { Dimensio }}$ & $\begin{array}{l}\text { Study } \\
\text { Comm } \\
\text {-unity }\end{array}$ & $\begin{array}{l}\text { Numb } \\
\text { er }(\mathbf{N})\end{array}$ & $\begin{array}{l}\text { Arithmet } \\
\text { ic Mean }\end{array}$ & $\begin{array}{c}\text { Standar } \\
\text { d } \\
\text { Deviati } \\
\text { on } \\
\end{array}$ & $\begin{array}{l}\text { Degre } \\
\text { es of } \\
\text { (DF) }\end{array}$ & $\begin{array}{c}\text { Valu } \\
\text { e of } \\
\mathbf{T}\end{array}$ & $\underset{\text { ce }}{\text { Significan }}$ \\
\hline & system & es & & & & & & \\
\hline \multirow[b]{2}{*}{3} & \multirow{2}{*}{$\begin{array}{l}\text { Social } \\
\text { relations } \\
\text { dimension } \\
\text { regarding } \\
\text { the } \\
\text { faculty } \\
\text { members } \\
\text { system }\end{array}$} & $\begin{array}{l}\text { Social } \\
\text { Scienc } \\
\text { es }\end{array}$ & 43 & 2.26 & 0.41 & \multirow[b]{2}{*}{96} & \multirow[b]{2}{*}{$\begin{array}{r}2.28 \\
2\end{array}$} & \multirow[b]{2}{*}{$*$} \\
\hline & & $\begin{array}{l}\text { Natural } \\
\text { Scienc } \\
\text { es }\end{array}$ & 55 & 2.06 & 0.43 & & & \\
\hline \multirow[b]{2}{*}{4} & \multirow{2}{*}{$\begin{array}{l}\text { Social } \\
\text { relations } \\
\text { dimension } \\
\text { regarding } \\
\text { the } \\
\text { university } \\
\text { system } \\
\end{array}$} & $\begin{array}{l}\text { Social } \\
\text { Scienc } \\
\text { es } \\
\end{array}$ & 43 & 1.99 & 0.45 & \multirow[b]{2}{*}{96} & \multirow{2}{*}{$\begin{array}{r}0.93 \\
6\end{array}$} & \multirow{2}{*}{$\begin{array}{l}\text { Non } \\
\text { Significant }\end{array}$} \\
\hline & & $\begin{array}{l}\text { Natural } \\
\text { Scienc } \\
\text { es }\end{array}$ & 55 & 1.91 & 0.43 & & & \\
\hline \multirow{2}{*}{\multicolumn{2}{|c|}{$\begin{array}{c}\text { Total } \\
\text { Dimensions }\end{array}$}} & $\begin{array}{l}\text { Social } \\
\text { Scienc } \\
\text { es }\end{array}$ & 43 & 2.33 & 0.27 & \multirow[b]{2}{*}{96} & \multirow[b]{2}{*}{$\begin{array}{r}2.51 \\
6\end{array}$} & \multirow{2}{*}{$\begin{array}{l}\text { Non } \\
\text { Significan } \\
\text { t }\end{array}$} \\
\hline & & $\begin{array}{l}\text { Natur } \\
\text { al } \\
\text { Scienc } \\
\text { es } \\
\end{array}$ & 55 & 2.2 & 2.24 & & & \\
\hline
\end{tabular}

** Significance at $(0.01)$

* Significance at $(0.05)$

The table above shows that: - There are statistically significant differences at a significance
level of (0.01) between the mean scores of non-users of social media from the social science disciplines and the mean scores of non-users of social media from natural science disciplines on the social relations dimension regarding the family system. The significance is for nonusers of social media from social science discipline.

There are statistically significant differences at a significance level of (0.05) between the mean scores of non-users of social media from social science disciplines and the mean scores of non-users of social media from natural science disciplines on the social relations dimensions regarding the faculty members system. The significance is for non-users of social media from social science disciplines.

There are statistically significant differences at a significance level of (0.05) between the mean scores of non-users of social media from the social science disciplines and the mean scores of non-users 
of social media from natural science disciplines on social relations scale as a whole. The significance is for the non-users of social media from social science disciplines.

There are no statistically significant differences between the mean scores of non-users of social media from social science disciplines and the mean scores of non-users of social media from natural science disciplines on the social relations scale regarding the friends system and the university system.

Thus, we accept the fourth hypothesis of the study: There are statistically significant differences between the mean scores of the non-users of social media from social sciences disciplines and the mean scores of the non-users of social media from natural sciences disciplines on the social relations scale.

\section{Discussion:}

The study sought to test hypotheses to determine if there are differences between university youth users and non-users of social media from natural science and social science disciplines, as well as the social relations with the surrounding systems such as friends, family and faculty members. The study found that university youth users of social media are more than non-users, and that social media does not affect their social relations since there were no differences between the scores of students in the theoretical and practical faculties. This may be due to the short duration of social media use. This finding contrasted with Hanan Shashou's study (2012), which indicated that social media affects social relations. This may be owing to the difference in the time of the studies' implementation and the difference in the study community. The finding related to the highest percentage of social media users being from natural science disciplines is may be due to the nature of their usage of social media, which is confirmed by the communication theory asserting the use of indirect audio-visual methods, like computers, in transferring knowledge from one person to another. This finding agreed with Moubarak's study (Hanaa F.A. Moubarak, 2016) "Internet Addiction list and Risk List of Adolescents Virtual Relations". The results of said study showed the diversity of adolescents' virtual relations risks including ethical, cultural, psychological, educational, health and family risks. They also showed that adolescents are more susceptible to psychological risk and less susceptible to behavioral risk and that 
there is a highly significant correlation between being at risk and the ability to manage it virtual relations and that the adolescents have different estimations of risks and high abilities to manage them, except for the educational risk.

- $\quad$ There are slight differences between non-users of the social media from social science disciplines and those from natural science disciplines. Non-users of social media from social science disciplines have a higher ability to form social relations than those from natural science disciplines. This may be due to the nature of social sciences that seeks to form positive relations with others. The current study differs from the previous studies in that it was applied to the nonaddicted users and the non-users of social media from both the theoretical and practical science disciplines. Thus, there are no significant differences in the social media impact on social relations among the university youth users and non-users of social media.

The previous studies confirmed that there are negative effects to social media. However, there are also positive effects to social media on communication and knowledge exchange between individuals. Those studies included Abbas Zaghloul's study, El Tayar Ben Fahd's study, and Wafaa Abdel Salam's study. This was also confirmed by the The study results indicated communication theory .

- The study results indicated the lack of differences between students social and natural science disciplines. Results also indicated the existence of relationship problems among male students more than female students, and among students dwelling in urban settings more than rural settings. Those results led to the identification of a number of indicators for social workers:

- 1. Social workers in the field of university youth care should give attention to strengthening social relations among university students in both social and natural science disciplines.

- 2. The social workers should focus on strengthening the social relations of male and female students.

- 3. The social workers should focus on strengthening the social relations of students from urban areas more than rural areas. 


\section{Recommendations:}

For the Egyptian universities to:

1. Raise the awareness of youth non-users of social media on its importance in acquiring knowledge, positive communications, and prevention against negative complications and risks.

2. Raise the awareness of university youth on the importance of positive usage of social media (such as Facebook, Twitter, and WhatsApp), through conducting seminars and lectures.

3 . Study the impact of social media on youth, especially at the present time, because of their impact on youth behavior and culture.

4. Enable social workers to play an effective role with university youth users of social media from both social and natural science disciplines.

\section{References:}

Abbas, H. Zaghloul, (2006) A Proposed guiding program from the perspective of group work to face the negative effects of the internet on university students, social work and humanities Journal, Issue 20, Vol 2.

Abdel Salama, W. Hafez, (2012) Social reflections of the internet as a form of digital technology, published research, Twenty-Fifth Conference at the Faculty of Social Work, Helwan, Part 5.

Abdul Gwad, Z. Sameh, (2017) Social media and the second generation of libraries, theories and applications, Dar Al Kitab Al Hadis.

Abdullatif, R. Ahmed and Dandarwi, A. Abbass, (2001) Social Work generalist practice skills and strategies, Giza, Al Ummaranya Publishing House.

Abdullatif, R. Ahmed, (1999) Models and skills of social work community organization; a Continuous integrated approach, Alexandria, Modern University Bureau.

Abu Al Maatty, M. Ali (1999) A Suggested conceptual Framework for developing university students care program, social work and humanities Journal, Helwan University, Faculty of Social Work.

Abu Al Maatty, M. Ali, (2008) Social work and the fields of professional practice, Cairo, Zahraa- ul- Shareq Library.

Ahmed, K., Community organization between Principles, basics, and theories, Cairo Modern Library.

Arabic Glossary, Al Wagieeze (1997) Dar Al Tahrir Publishing and Printing.

Badawi, A. Zaki (1993) Glossary of social science vocabulary, Cairo, Dar Al Kitab Al Masri. 
Chuang, S. et al (2015) An Exploration of the relationship between internet self-efficacy and Sources of internet Self-Efficacy among Taiwanese university Students, computers in human behavior. Vol.48

Deuter, M. et al (2015) Oxford Advanced learners dictionary, Oxford University, United Kingdom.

Diana E. Weiss, (2014) The Relationship between internet Social media, social anxiety, self-esteem, narcissism, and gender among College Students. dissertation abstracts International: Section B: The Sciences and Engineering. Vol.74

Fahd, E. (2014) Social media networks and its impact on values among University Students, King Seoud University, Kingdom of Saudi Arabia.

Hanaa F. A. Moubarak (2016) Risk assessment of adolescents' virtual relations, Egyptian Journal of Social Work.

Khateiry, M. El Sayed (2014) The Impact of internet on the social withdrawal of university youth, Published research in the Journal of Social Work and Human Sciences Studies, Issue no. 36.

Mohammed, A., (2011) Contemporary theoretical tendencies for community organization, Alexandria, The Modern University Office.

Nasser, H. Ghani, 2012, Social interactions and relationships, Babel University, Faculty of Arts, Sociology Department.

Saleh, K. Saleh (2012) The Effect of social media networks on The Social value Of University Students, Social Science and humanities Journal, Helwan University, Faculty of Social Work, No.33, Volume 1.

Shashou', H. (2012) The Impact of electronic social media on Social relations among female students, MA thesis, King Abdul Aziz University, Kingdom of Saudi Arabia.

Soliman, H. Hassan, Abdelmaguid H, El Bahr M (2005) Generalist practice of social work with group, agency and community, beirut: University Institution for publishing and distribution.

Yang, C. et al (2015) From Relationship to information: A Study of twitter and Facebook Usage in Terms of social network size among College Students, U.S.A 